\title{
Diet and Life-History Traits of Savannah Dwelling Waterbirds in Southern Africa: Implications for Their Conservation Status
}

\author{
Tawanda Tarakini ${ }^{1,2,3, * \mathbb{D}}$, Innocent Mabika ${ }^{1,3}$, Tongayi Mwedzi ${ }^{1} \mathbb{D}$, Peter Mundy ${ }^{4}$ and Hervé Fritz $^{3,5,6}$ \\ 1 School of Wildlife, Ecology and Conservation, Chinhoyi University of Technology, Bag, \\ Chinhoyi 7724, Zimbabwe; mabikainnocent@gmail.com (I.M.); tmwedzi@cut.ac.zw (T.M.) \\ 2 Research and Education for Sustainable Actions, Katanda, Chinhoyi 9934, Zimbabwe \\ 3 Hwange LTSER/Zone Atelier Hwange-CNRS HERD (Hwange Environmental Research Development) \\ Program, Hwange National Park, Dete Box 62, Zimbabwe; Herve.Fritz@univ-lyon1.fr \\ 4 Department of Forest Resources and Wildlife Management, National University of Science and Technology, \\ Bulawayo P.O. Box AC 939, Zimbabwe; pmundy@nust.ac.zw \\ 5 Sustainability Research Unit, George Campus, Nelson Mandela University, Madiba Drive, Private Bag X6531, \\ George 6530, South Africa \\ 6 Laboratoire de Biométrie et Biologie Evolutive, CNRS UMR 5558, Université Claude Bernard Lyon 1, Bât. \\ Gregor Mendel, 43 bd. du 11 Novembre 1918, CEDEX, 69622 Villeurbanne, France \\ * Correspondence: tawandatizora@gmail.com or ttarakini@cut.ac.zw
}

Citation: Tarakini, T.; Mabika, I.; Mwedzi, T.; Mundy, P.; Fritz, H. Diet and Life-History Traits of Savannah Dwelling Waterbirds in Southern Africa: Implications for Their Conservation Status. Birds 2021, 2, 173-184. https://doi.org/10.3390/ birds2020013

Academic Editor: Jukka Jokimäki

Received: 11 March 2021

Accepted: 20 April 2021

Published: 11 May 2021

Publisher's Note: MDPI stays neutral with regard to jurisdictional claims in published maps and institutional affiliations.

Copyright: (c) 2021 by the authors. Licensee MDPI, Basel, Switzerland. This article is an open access article distributed under the terms and conditions of the Creative Commons Attribution (CC BY) license (https:// creativecommons.org/licenses/by/ $4.0 /)$.
Simple Summary: Species population declines worldwide are worrisome. This study was driven by the interest to know if population trends of waterbird species are affected by their diet, factors linked to reproduction and growth. The cases of 163 waterbird species found in southern Africa were considered. Close to two-thirds of these species are in decline worldwide. Using the variety and size of diet items, this study discovered that species could be grouped into four categories, and species that are consumed as food by people could fit into one group. The groups with waterbird species that feed on small and large prey items had higher probabilities of having declining population trends when compared to those feeding on medium-sized items. Amphibians, coleopterans, crustacea, molluscs and tunicates were consumed by waterbird species across the four waterbird categories. If current climate change trends continue to suppress the populations of these prey bases, then waterbirds are also in imminent danger. It will be critical to control human disturbance in wetlands.

Abstract: This study evaluates the relative contribution of reproduction-based life history traits and diet to the population trends in waterbirds from southern Africa. Life history traits (clutch size, incubation period, fledging time, body mass and generation length), diet (prey weight, body lengths and number of taxa represented in its diet (NTD)) and conservation status (declining/not declining) of 163 waterbird species were reviewed. An index of diet generalism was created based on NTD. Cluster analysis was applied on life history traits to define groups of waterbirds. Binomial regressions were used to test if population trends were different across cluster groups and diet variables. Four clusters of waterbirds were defined, with most waterfowl clustering together. Species that feed on small and large prey had higher probabilities of declining ( 0.17 and 0.26 , respectively) compared to those feeding on medium-sized prey (0.08). Amphibians, coleopterans, crustacea, molluscs and tunicates were used by species in all clusters, and the risk of waterbird populations declining further are high given the current dwindling of the prey base. The large proportions of declining species $(61 \%)$ in waterbirds, which have constrained habitats, calls for continued efforts to mitigate disturbances to wetlands.

Keywords: waterbirds; diet; life history traits; index of diet generalism

\section{Introduction}

The southern African region is endowed with a variety of waterbirds that feed in various coastal and inland habitats [1]. The waterbird diet has been central in many studies 
and its quality and quantity remains a conservation issue. Traits that promote dietary flexibility in a species can be beneficial given the global shifts in habitats [2], resources and climate [3]. Knowing that waterbird prey are responding at different rates to these global shifts [4], an exploration of the traits and diet requirements of species that are associated with various conservation states can provide vital information to be used for conservation planning.

Most life history traits in birds, in particular those linked to reproduction (e.g., clutch size, incubation period and fledging time), are positively related to individual body mass [5,6] and generation length [7]. It has been established that in evolutionary biology, traits do not evolve in isolation, but in a coordinated way with other characteristics that may include behaviour, physiology, morphology, and life histories [8]. Particular characteristics in life history traits could make some species more vulnerable to population declines if environmental conditions change [9]. Additionally, several studies have documented the dietary requirements of waterbird species $[1,10,11]$ and species with narrow diet niches (specialist) could be more prone to changes in habitat and resources [2,12]. Specialist species are often associated with lower dispersal abilities [13], are more strongly regulated by intra-specific competition [14], and are less able to cope with environmental stochasticity than generalists species [12]. Already, various authors have linked dynamics in climate, disturbances and exploitation to waterbird trends $[15,16]$. Thus, future predictions of waterbird changes may be achieved given information on the life history traits of species [9] and their dietary requirements and flexibility.

Some prey may be considered as important in an ecosystem by considering the number of organisms that rely on them $[8,10,17]$. Environmentalists should, therefore, monitor the trends of such prey species as their population declines may have domino effects on other species that are reliant on them. In the interior of southern Africa, most wetlands have freshwater systems which are heavily utilised by humans [10,18], hence, the quality and quantity of water in the wetlands are also affected. Such dynamics may be important to model future trends of waterbird species.

This study attempts to understand the associations between conservation status, diet and life history traits of waterbird species found in southern Africa. It is predicted that large species with long incubation and fledging periods (hence slow rates of adapting to stochastic events) could be experiencing more significant declining trends given the current environmental perturbations compared to smaller species. Additionally, specialists (those with narrow diet niches) are expected to demonstrate more declining trends as they are less able to cope with environmental stochasticity [12] compared to generalists. It is considered that these two approaches (diet and reproduction) will reveal significant underlying mechanisms that will be helpful to conservation.

\section{Materials and Methods}

Diet studies and published information for 163 waterbird species that have been recorded in southern Africa (Botswana, Madagascar, Malawi, Mozambique, Namibia, Swaziland, Zambia and Zimbabwe) were reviewed and the taxa they ingest were recorded. The sources used various methods including direct observations [19], regurgitate analysis [17], and scat analysis [20] to determine species diet. The number of taxa in the diet (NTD) were summarised per species. By considering the mean weight and size (body lengths) of all the prey items in a species' diet, each species was assigned to its respective size class. This was achieved through modification of the methods by Arzel [21] to come up with diet weight classes: $\mathrm{A}=0-50 \mathrm{~g}, \mathrm{~B}=51-100 \mathrm{~g}, \mathrm{C}=101-500 \mathrm{~g}$ and $\mathrm{D}=$ weight $>501 \mathrm{~g}$. The classification according to diet item lengths were considered as $1=0-10 \mathrm{~mm}, 2=11-50 \mathrm{~mm}, 3=$ length $>50 \mathrm{~mm}$. For the waterbird species, a review on their mean clutch size, incubation period (days), fledging time (days), body mass (in kilograms) and generation length (in years), movement patterns (migrations) and their global population trend was conducted following information provided on the Birdlife International website on www.datazone.birdlife.org/species (accessed on 4 February 2018). 
Waterbird population trends from Birdlife International were re-categorised as either declining or not declining (stable/increasing). A case-by-case simplification of the known ecological guilds of waterbirds was done by considering the main components of their diet, a modified method from Liordos [22], and some rare species were grouped according to their closest guild. The results of the grouping exercise retained five broad categories of waterbirds as herbivores (largely feeding on vegetation matter), insectivores (mainly feeding on insects and other aquatic invertebrates such as crustacea and annelids), piscivores (predominantly feeding on fish and amphibians), semi-omnivores (consuming a variety of invertebrates and also plant matter), and omnivores (when diet consisted of items from herbivores, insectivores and piscivores). Raptors were excluded from the dataset as they frequently forage in non-wetland areas [20].

The gap statistic method [23] was used to determine the optimal number of clusters that best describe the life history data (clutch size, incubation period, fledging time, body mass and generation length) using the NbClust package [24]. This optimal number was then used in carrying out the k-means partition cluster analysis to create reproduction-based clusters that described the data. Thus, each species was assigned to its resulting cluster.

Correlations tests between all the life history trait variables were conducted with the aim of dropping those that are highly correlated (correlation coefficient $r>0.8$ [25]). An "index of diet generalism" (i.e., a score of how a species could be considered a generalist or specialist) was derived by taking $\log _{10}$ (NTD/median of NTD for all species in the dataset). This index of diet generalism ranged from positive values (generalist species) to negative (specialist ones). Chi-squared tests were used to investigate the relationships between waterbird allocated clusters and the global trends. Binomial logistic regressions were performed to model species global population trends to the single and interactive effects of species allocated cluster, diet weight, diet lengths, diet guild, and index of diet generalism. The best model was selected using the lowest Akaike information criteria [26] that retains the most influential variables for global population trends. All analyses were done in the R package for Statistical Computing [27].

\section{Results}

The gathered waterbird dataset consisted of resident species (85), Afrotropical migrants (36) and Palaearctic migrants (42) ( $n=163$, Appendix A). Although most of these species (134) are considered to at least be of concern by the IUCN, 7 are vulnerable, 15 near threatened and 7 are endangered. Clutch size was negatively related to generation length $(\mathrm{r}=-0.24, p=0.002)$ but there were no correlations between (1) clutch size and incubation period ( $\mathrm{r}=0.12, p=0.139)$ or (2) clutch size and body mass $(\mathrm{r}=0.01, p=0.908)$. The rest of the relationships across the life history traits were significantly correlated, with $r$ values ranging from 0.33 to 0.63 ( $p<0.001$ in all cases).

A large proportion of waterbirds in the dataset $(48 \%)$ rely on small diet items (class 1$)$. Insectivores formed the largest guild with $32 \%$ of all species. The herbivorous and omnivorous species were found to be declining most strongly (Table 1), with $80 \%$ and $71 \%$ of each guild, respectively.

Table 1. Distribution of waterbird population trends across diet body lengths and allocated guilds.

\begin{tabular}{ccccccccc}
\hline & \multicolumn{3}{c}{ Diet Body Length Classes } & \multicolumn{5}{c}{ Waterbird Allocated Guilds } \\
\cline { 2 - 9 } Global Status & $\mathbf{1}$ & $\mathbf{2}$ & $\mathbf{3}$ & Herb & Insect & Semi-Omniv & Omniv & Pisci \\
\hline Declining & 55 & 20 & 24 & 8 & 31 & 8 & 24 & 28 \\
Not declining & 23 & 32 & 9 & 2 & 21 & 10 & 10 & 21 \\
\hline Total & 78 & 52 & 33 & 10 & 52 & 18 & 34 & 49 \\
\hline
\end{tabular}

Note: Herb $=$ herbivores, Insect $=$ insectivores, Omniv $=$ omnivores and Pisci $=$ piscivores. 


\subsection{Clusters on Life History Traits}

The data optimally describe four clusters, as shown in Figure 1, with clusters one to four having 83, 50, 10 and 20 species, respectively. Dimension 1 seems to separate species according to body mass and generation length, where large long-living species had negative values (cranes, storks and flamingos in cluster three) and the small short living ones tend to have positive values (e.g., crakes, jacanas, coursers, mostly in clusters one and two). Dimension 2 seems to separate species with large clutch sizes (notably the wildfowl like ducks and geese in cluster four) from those with smaller ones (clusters two and three). There is considerable overlap between clusters one, two and four in terms of incubation and fledging periods.

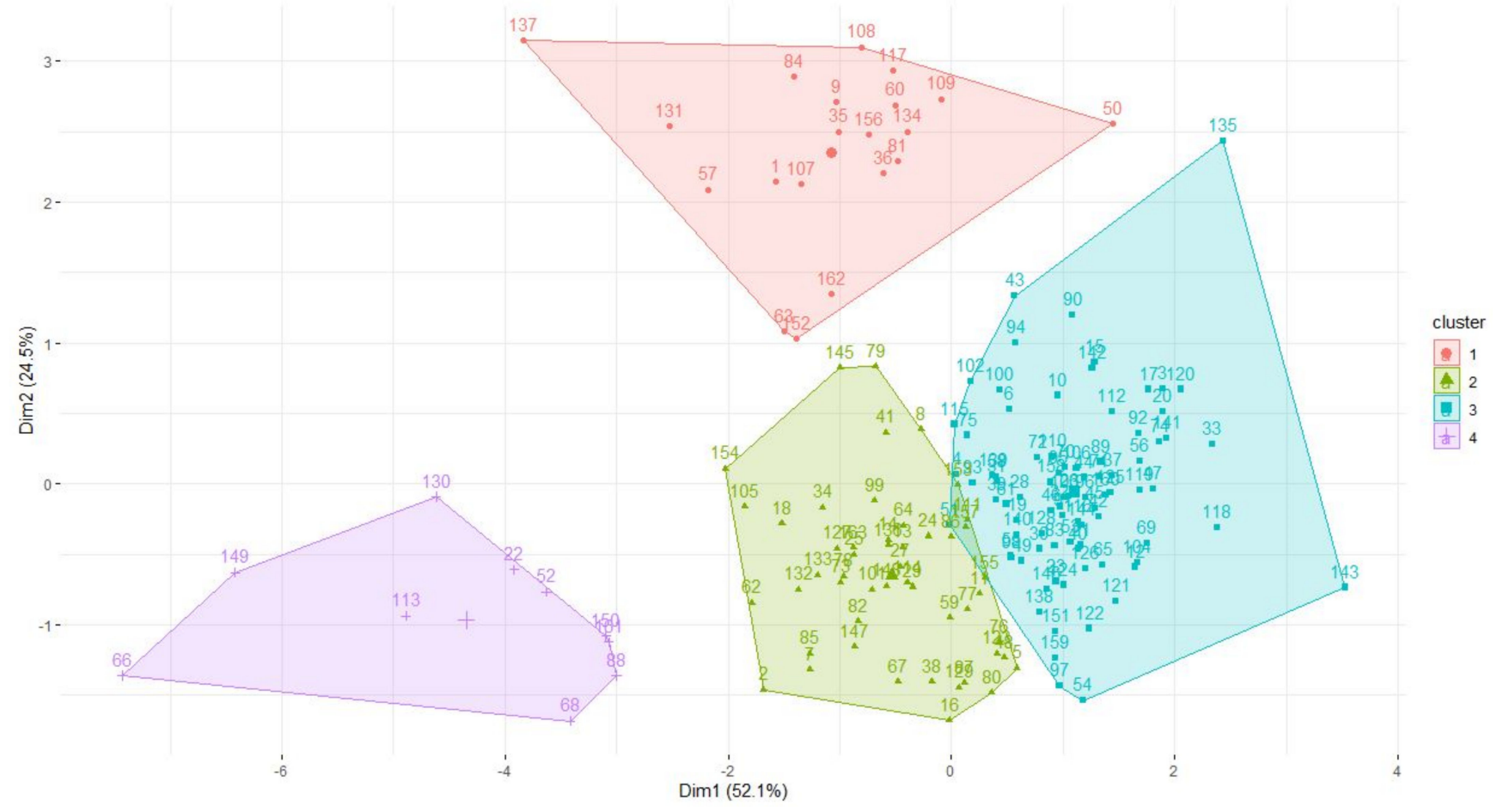

Figure 1. Clusters formed from analysing number of NTD, clutch size, incubation period, fledging time, body mass and generation length of waterbirds found in southern Africa. See Appendix A for the species represented by number codes.

Most $(90 \%)$ herbivorous waterbirds are in cluster four. Cluster one contains the majority of insectivores $(60 \%)$, semi-omnivores $(61 \%)$, omnivores $(65 \%)$ and the streakybreasted flufftail was also in this cluster. The diet of species in cluster one represented all the diet taxa reviewed in this study but crustacea, tunicates, annelids, coleopterans and molluscs were predominantly consumed (Table 2). Piscivores were mostly in cluster three $(53 \%)$ and cluster one (37\%). Cluster two and three species' dominant diet items included tunicates, crustacea, small amphibians and coleopterans, although the diet tended to be more specialised for cluster two (generality index of -0.05 ) compared to cluster three $(-0.14)$. 
Table 2. Waterbird prey in southern Africa and their representation in the diets of waterbird clusters.

\begin{tabular}{|c|c|c|c|c|}
\hline \multirow[b]{2}{*}{ Prey Item } & \multicolumn{4}{|c|}{ Percentage of Birds Consuming Prey Item } \\
\hline & Cluster 1 & Cluster 2 & Cluster 3 & Cluster 4 \\
\hline Algae/plankton & 7 & 2 & - & 10 \\
\hline Annelids & 49 & 38 & - & 20 \\
\hline Arachnids & 25 & 6 & - & - \\
\hline Bird eggs & 6 & 10 & - & - \\
\hline Birds & 6 & 26 & 30 & - \\
\hline Chilopods & 1 & - & - & - \\
\hline Chironomids & 1 & 2 & - & 5 \\
\hline Clinids & 1 & - & - & - \\
\hline Coleopterans & 39 & 32 & - & 20 \\
\hline Crustaceans & 59 & 62 & 50 & 55 \\
\hline Culicidae & 5 & - & - & - \\
\hline Cyanobacteria & 5 & - & 10 & - \\
\hline Demapterans & 17 & 6 & - & 15 \\
\hline Diatoms & 2 & - & 10 & 5 \\
\hline Diplopods & 6 & 4 & - & 5 \\
\hline Dipterans & 47 & 22 & 10 & 20 \\
\hline Echinoderms & 4 & - & - & - \\
\hline Ephemeropterans & 30 & 8 & 10 & - \\
\hline Fruits & 7 & 6 & 20 & 90 \\
\hline Gastropods & 20 & 12 & 20 & 05 \\
\hline Hemipterans & 37 & 2 & - & 30 \\
\hline Homopterans & 25 & 12 & 10 & 5 \\
\hline Hymenoptera & 35 & 16 & - & - \\
\hline Isopterans & 34 & 12 & - & 30 \\
\hline Leaves & 23 & 10 & 20 & 90 \\
\hline Lepidopterans & 35 & 16 & 20 & 15 \\
\hline Mantids & 17 & 8 & - & 10 \\
\hline Molluscs & 46 & 54 & 50 & 40 \\
\hline Odonata & 25 & 18 & - & 5 \\
\hline Orthopterans & 30 & 28 & 20 & 40 \\
\hline Roots/tubers & 22 & 12 & 10 & 85 \\
\hline Rotifers & 5 & 2 & 10 & - \\
\hline Scorpiones & 8 & 8 & 10 & 20 \\
\hline Seeds & 39 & 18 & 30 & 80 \\
\hline Small amphibians & 30 & 42 & 60 & 20 \\
\hline Small mammals & 7 & 24 & 20 & - \\
\hline Small reptiles & 11 & 20 & 50 & - \\
\hline Trichopterans & 17 & 12 & 10 & 20 \\
\hline Tunicates & 54 & 66 & 50 & 30 \\
\hline
\end{tabular}

\subsection{Diet and Life History Traits in Relation to Population Trends}

The majority $(61 \%, n=99)$ of the waterbirds presented in this study had declining population trends. Clusters one to three had a greater proportion of species that had declining population trends $(68,52$ and $70 \%$, respectively) compared to those in cluster four $(50 \%)$. However, the population trends were not significantly different across the four clusters $\left(x^{2}=4.501, \mathrm{df}=3, p=0.212\right)$. The best model explaining waterbird population trends retained only the diet body lengths (Appendix B). The diet body length (across three classes) significantly predicted population trends of waterbirds $(\beta=15.819, \mathrm{df}=2$, $p=0.0004)$, as shown in Table 3 . 
Table 3. Results of model explaining the significant factor related to waterbird global population trends in Southern Africa.

\begin{tabular}{ccccc}
\hline Variable & Estimate & Std. Error & Z Value & $p$ Value \\
\hline Intercept & -0.8718 & 0.2483 & -3.511 & 0.0004 \\
Diet body length $11-50 \mathrm{~mm}$ & 1.3418 & 0.378 & 3.55 & 0.0004 \\
Diet body length $>50 \mathrm{~mm}$ & -0.109 & 0.4631 & -0.235 & 0.8139 \\
\hline
\end{tabular}

The species that feed on small and large prey (diet body length classes one and three) had higher probabilities of declining ( 0.17 and 0.26 , respectively) compared to those feeding on class two (0.08). Although the diet generality indices were slightly higher for species feeding on large prey items (Figure 2), this did not significantly affect the likelihood of decline.

a)

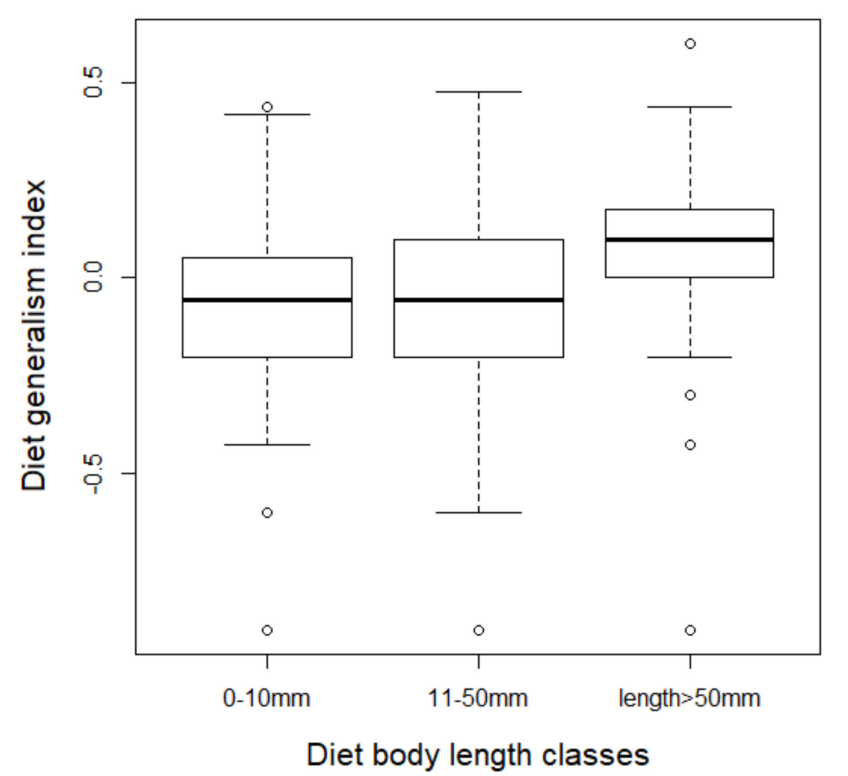

b)

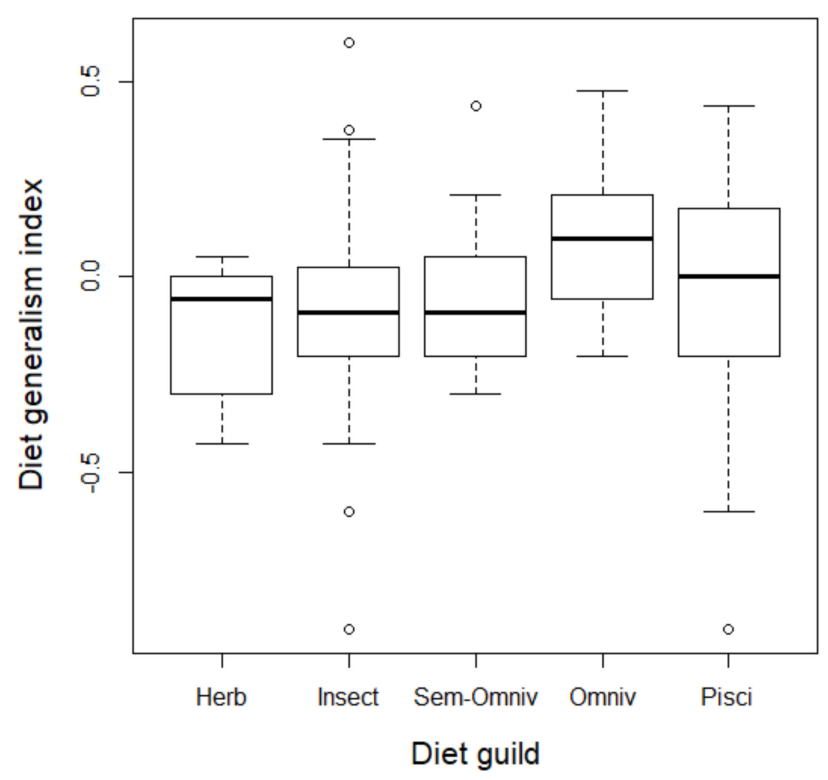

Figure 2. Variation of the diet generality index for waterbirds of southern Africa across their (a) diet body length classes and (b) diet guilds. The lines and bars represent the median and the quartiles. In plot (b), Herb = herbivores, Insect $=$ insectivores, Omniv = omnivores and Pisci $=$ piscivores.

\section{Discussion}

Analysis of reproduction based life history traits of waterbirds in southern Africa resulted in four clusters of species. Contrary to this study's hypothesis, there was no significant relationship between waterbird population trends and the clusters integrating reproduction based life history traits. Many waterbird species have declining population trends globally and in all clusters described in this study, at least $50 \%$ of the members had declining population trends. It is important to highlight implications for specific guilds. This study illustrated that not only species with small diet items have higher proportions of decline, but also those with large diet items (despite them having higher indices of diet generalism). Due to the sensitivity of most waterbird prey species to changes in water levels, pollution and vegetation attributes [28,29], the waterbirds relying on these species may be at greater risk of decline. It can be argued that the species consuming larger prey items have higher proportions of decline because such species are mostly large-bodied [30], and therefore, more prone to disturbances and habitat fragmentation [31] when compared to small ones. Large bodied waterbird species are also targeted by hunters [32].

Although the probability of a species having a declining population status was unrelated to its index of diet generalism, all the species that grouped in cluster four are 
waterfowl (dominated by ducks and geese that feed on small food items). This finding is important, as the diet of waterfowl is limited to water bodies [2,33] and they also face pressure from harvesting by humans [34,35], disease risk [36] and other global climate and habitat change mediated challenges $[10,37]$. For example, some people involved in waterfowl hunting insist on sustaining this activity [38] despite the conservation risks to the populations globally. Additionally, most of these species (90\%) are herbivorous, having lower indices of diet generalism, and hence, could be less able to cope with environmental stochasticity [12]. Conservationists, therefore, need to strengthen mitigative efforts against the main drivers such as habitat destruction and hunting [10].

Cluster one contained species from all the diet guilds (a "mixed bag" representing all the prey items reviewed in this study). Insectivore and omnivorous species were predominant in this mixed bag, a description fitting waders [39]. Since most waders are migratory [40], they face different constraints on the flyway [41] and this possibly explains the high proportion $(68 \%)$ of those with declining populations. Additionally, waders may have the ability to exploit various prey items at different stopping sites [42], thus, explaining the tendency of being omnivorous.

This study revealed that tunicates, crustacea, amphibians, molluscs and coleopterans are constantly at the top of the diet of all the allocated waterbird clusters. With the current global declines in these prey items [43,44], this study also emphasizes the threat warnings particularly in relation to the species that feed on small items and those with low indices of diet generalism (cluster three). It is acknowledged that these listed food items do not necessarily imply the importance of their biomass in the diet, particularly for species in cluster three, which are large-bodied (as waterbirds may make meals from fewer but larger prey items). Additionally, the challenges associated with segregating diet items are acknowledged, since most published materials classify them in very broad taxonomic groupings and each item can vary in size from half a millimetre to several centimetres within a given taxon [11].

\section{Conclusions}

This study has shown that the size (lengths) of prey items is important in explaining population trends of waterbirds, and exposes the immediate risks faced by wildfowl species and those feeding on large prey in southern Africa if wetland conditions continue to deteriorate. The study also illustrated the importance of distinguished waterbird prey items such as tunicates, crustacea, amphibians and molluscs in the diet of species included in this study. It is possible that this study failed to detect some differences in population trends across specific guilds because the waterbird guild is already a specialised class of birds [45]. There is a need for united efforts in mitigating wetland disturbances, chiefly habitat destruction and hunting as these directly affect the prey base.

Author Contributions: Conceptualization, T.T. and T.M.; methodology, T.T., H.F. and I.M.; software, H.F.; validation, T.T., P.M. and I.M.; formal analysis, T.T.; investigation, I.M. and T.T.; resources, H.F. and T.T.; data curation, H.F., T.T. and I.M.; writing—original draft preparation, T.T.; writing—review and editing, H.F.; visualization, T.T. and T.M.; supervision, H.F. and P.M.; project administration, H.F.; funding acquisition, T.T. All authors have read and agreed to the published version of the manuscript.

Funding: This work was funded by the Ministère Français des Affaires Etrangères through the FSP-RenCaRe project, grant number CC04.

Institutional Review Board Statement: Not applicable.

Data Availability Statement: The waterbird trends data presented in this study are openly available on the birdlife international website on www.datazone.birdlife.org/species (accessed on 4 February 2018).

Acknowledgments: We thank the framework of the Research Platform 'Production and Conservation in Partnership' (RP-PCP) for supporting the student with administration of the grant. We also thank the Zone Atelier Hwange-Hwange LTSER for hosting the lead author during the course of study. 
Conflicts of Interest: The authors declare no conflict of interest. The funders had no role in the design of the study; in the collection, analyses, or interpretation of data; in the writing of the manuscript, or in the decision to publish the results.

\section{Appendix A}

Table A1. Groups of southern African waterbird species from life-history based cluster analysis alongside their recategorised ecological guilds and codes as used in Figure 1 . Semi-omn = semi-omnivores, Dec $=$ declining.

\begin{tabular}{|c|c|c|c|c|c|}
\hline Cluster & Code & Local Name & Scientific Name & Diet Guild & Global Status \\
\hline \multirow[t]{50}{*}{1} & 3 & African Crake & Crex egregia & Semi-omn & Not Dec \\
\hline & 4 & African Darter & Anhinga rufa & Piscivores & Dec \\
\hline & 6 & African Jacana & Actophilornis africanus & Insectivores & Not Dec \\
\hline & 10 & African Rail & Rallus caerulescens & Omnivores & Not Dec \\
\hline & 12 & African Snipe & Gallinago nigripennis & Insectivores & Dec \\
\hline & 15 & Allen's Gallinule & Porphyrio alleni & Omnivores & Dec \\
\hline & 17 & Baillon's Crake & Porzana pusilla & Insectivores & Dec \\
\hline & 19 & Bar-tailed Godwit & Limosa lapponica & Omnivores & Dec \\
\hline & 20 & Black Crake & Zapornia flavirostra & Omnivores & Dec \\
\hline & 21 & Black Heron & Egretta ardesiaca & Piscivores & Not Dec \\
\hline & 23 & Black Tern & Chlidonias niger & Piscivores & Dec \\
\hline & 26 & Black-necked Grebe & Podiceps nigricollis & Insectivores & Dec \\
\hline & 28 & Black-tailed Godwit & Limosa limosa & Omnivores & Dec \\
\hline & 30 & Black-winged Pratincole & Glareola nordmanni & Insectivores & Dec \\
\hline & 31 & Black-winged Stilt & Himantopus himantopus & Insectivores & Not Dec \\
\hline & 32 & Bronze-winged Courser & Rhinoptilus chalcopterus & Insectivores & Not Dec \\
\hline & 33 & Buff-spotted Flufftail & Sarothrura elegans & Semi-omn & Not Dec \\
\hline & 37 & Caspian Plover & Charadrius asiaticus & Semi-omn & Dec \\
\hline & 39 & Cattle Egret & Bubulcus ibis & Insectivores & Not Dec \\
\hline & 40 & Chestnut-banded Plover & Charadrius pallidus & Insectivores & Not Dec \\
\hline & 42 & Common Greenshank & Tringa nebularia & Insectivores & Not Dec \\
\hline & 43 & Common Moorhen & Gallinula chloropus & Omnivores & Not Dec \\
\hline & 44 & Common Redshank & Tringa totanus & Insectivores & Dec \\
\hline & 45 & Common Ringed Plover & Charadrius hiaticula & Insectivores & Dec \\
\hline & 46 & Common Sandpiper & Actitis hypoleucos & Omnivores & Dec \\
\hline & 47 & Common Snipe & Gallinago gallinago & Omnivores & Dec \\
\hline & 49 & Common Whimbrel & Numenius phaeopus & Insectivores & Dec \\
\hline & 51 & Crowned Cormorant & Microcarbo coronatus & Piscivores & Not Dec \\
\hline & 53 & Curlew Sandpiper & Calidris ferruginea & Insectivores & Not Dec \\
\hline & 54 & Damara Tern & Sternula balaenarum & Piscivores & Dec \\
\hline & 55 & Dimorphic egret & Egretta garzetta dimorpha & Piscivores & Not Dec \\
\hline & 56 & Dwarf Bittern & Ixobrychus sturmii & Piscivores & Dec \\
\hline & 58 & Eurasian Curlew & Numenius arquata & Omnivores & Dec \\
\hline & 61 & Glossy Ibis & Plegadis falcinellus & Insectivores & Dec \\
\hline & 65 & Great Snipe & Gallinago media & Insectivores & Dec \\
\hline & 69 & Greater Painted Snipe & Rostratula benghalensis & Omnivores & Dec \\
\hline & 70 & Greater Sandplover & Charadrius leschenaultii & Insectivores & Not Dec \\
\hline & 71 & Green Sandpiper & Tringa ochropus & Omnivores & Not Dec \\
\hline & 72 & Green-backed Heron & Butorides striata & Piscivores & Dec \\
\hline & 74 & Grey Phalarope & Phalaropus fulicarius & Semi-omn & Not Dec \\
\hline & 75 & Grey Plover & Pluvialis squatarola & Insectivores & Dec \\
\hline & 83 & Kitlitz Plover & Charadrius pecuarius & Insectivores & Dec \\
\hline & 89 & Lesser Jacana & Microparra capensis & Insectivores & Dec \\
\hline & 90 & Lesser Moorhen & Gallinula angulata & Semi-omn & Dec \\
\hline & 91 & Lesser Sandplover & Charadrius mongolus & Insectivores & Not Dec \\
\hline & 92 & Little Bittern & Ixobrychus minutus & Piscivores & Dec \\
\hline & 93 & Little Egret & Egretta garzetta & Piscivores & Not Dec \\
\hline & 94 & Little Grebe & Tachybaptus ruficollis & Insectivores & Dec \\
\hline & 95 & Little Ringed Plover & Charadrius dubius & Insectivores & Dec \\
\hline & 96 & Little Stint & Calidris minuta & Omnivores & Dec \\
\hline
\end{tabular}


Table A1. Cont.

\begin{tabular}{|c|c|c|c|c|c|}
\hline Cluster & Code & Local Name & Scientific Name & Diet Guild & Global Status \\
\hline & 97 & Little Tern & Sternula albifrons & Piscivores & Dec \\
\hline & 98 & Long-tailed Cormorant & Microcarbo africanus & Piscivores & Dec \\
\hline & 100 & Maccoa Duck & Oxyura maccoa & Omnivores & Dec \\
\hline & 102 & Madagascar Jacana & Actophilornis albinucha & Semi-omn & Dec \\
\hline & 103 & Madagascar Pond Heron & Ardeola idae & Piscivores & Dec \\
\hline & 104 & Madagascar Snipe & Gallinago macrodactyla & Semi-omn & Dec \\
\hline & 106 & Marsh Sandpiper & Tringa stagnatilis & Insectivores & Dec \\
\hline & 110 & Pacific Golden Plover & Pluvialis fulva & Insectivores & $\mathrm{Dec}$ \\
\hline & 112 & Pied Kingfisher & Ceryle rudis & Piscivores & Dec \\
\hline & 115 & Red Knobbed Coot & Fulica cristata & Semi-omn & $\mathrm{Dec}$ \\
\hline & 116 & Red Knot & Calidris canutus & Omnivores & Dec \\
\hline & 118 & Red-chested Flufftail & Sarothrura rufa & Omnivores & $\mathrm{Dec}$ \\
\hline & 119 & Red-necked Phalarope & Phalaropus lobatus & Omnivores & Dec \\
\hline & 120 & Red-tailed Flufftail & Sarothrura affinis & Semi-omn & Dec \\
\hline & 121 & Red-winged Pranticole & Glareola pratincola & Insectivores & Dec \\
\hline & 122 & Rock Pratincole & Glareola nuchalis & Insectivores & Dec \\
\hline & 124 & Ruddy Turnstone & Arenaria interpres & Omnivores & Dec \\
\hline & 125 & Ruff & Philomachus pugnax & Omnivores & Dec \\
\hline & 126 & Rufous-bellied Heron & Ardeola rufiventris & Piscivores & Dec \\
\hline & 128 & Sanderling & Calidris alba & Insectivores & Not Dec \\
\hline & 135 & Spotted Crake & Porzana porzana & Omnivores & Not Dec \\
\hline & 138 & Spur-winged Lapwing & Vanellus spinosus & Semi-omn & Not Dec \\
\hline & 139 & Squacco Heron & Ardeola ralloides & Piscivores & Dec \\
\hline & 140 & Staty Egret & Egretta vinaceigula & Piscivores & Dec \\
\hline & 141 & Streaky-breasted Flufftail & Sarothrura boehmi & Herbivores & Dec \\
\hline & 142 & Stripped Crake & Amaurornis marginalis & Insectivores & Dec \\
\hline & 143 & Temminck Courser & Cursorius temminckii & Semi-omn & Not Dec \\
\hline & 144 & Terek Sandpiper & Xenus cinereus & Omnivores & Dec \\
\hline & 146 & Three-banded Plover & Charadrius tricollaris & Insectivores & Dec \\
\hline & 151 & White Winged Tern & Chlidonias leucopterus & Insectivores & Not Dec \\
\hline & 158 & White-throated Rail & Dryolimnas cuvieri & Omnivores & Not Dec \\
\hline & 159 & Wiskered Tern & Chlidonias hybrida & Piscivores & Not Dec \\
\hline & 160 & Wood Sandpiper & Tringa glareola & Omnivores & Not Dec \\
\hline \multirow[t]{24}{*}{2} & 2 & African Black Oystercatcher & Haematopus moquini & Insectivores & Not Dec \\
\hline & 5 & African Finfoot & Podica senegalensis & Insectivores & Dec \\
\hline & 7 & African Openbill Stork & Anastomus lamelligerus & Piscivores & Dec \\
\hline & 8 & African Purple Swamphen & Porphyrio porphyrio & Omnivores & Dec \\
\hline & 11 & African Skimmer & Rynchops flavirostris & Piscivores & Dec \\
\hline & 13 & African Spoonbill & Platalea alba & Insectivores & Not Dec \\
\hline & 14 & African Wattled Lapwing & Vanellus senegallus & Semi-omn & Not Dec \\
\hline & 16 & Arctic Tern & Sterna paradisaea & Piscivores & Dec \\
\hline & 18 & Bank Cormorant & Phalacrocorax neglectus & Piscivores & $\mathrm{Dec}$ \\
\hline & 24 & Black-crowned Night Heron & Nycticorax nycticorax & Omnivores & Dec \\
\hline & 25 & Black-headed Heron & Ardea melanocephala & Insectivores & Not Dec \\
\hline & 27 & Blacksmith Lapwing & Vanellus armatus & Insectivores & Not Dec \\
\hline & 29 & Black-winged Lapwing & Vanellus melanopterus & Insectivores & Dec \\
\hline & 34 & Cape Cormorant & Phalacrocorax capensis & Piscivores & Dec \\
\hline & 38 & Caspian Tern & Hydroprogne caspia & Piscivores & Dec \\
\hline & 41 & Common Bittern & Botaurus stellaris & Piscivores & Dec \\
\hline & 48 & Common Tern & Sterna hirundo & Piscivores & Not Dec \\
\hline & 59 & Franklin's Gull & Larus pipixcan & Insectivores & Not Dec \\
\hline & 62 & Goliath Heron & Ardea goliath & Piscivores & Not Dec \\
\hline & 64 & Great Egret & Ardea alba & Piscivores & Dec \\
\hline & 67 & Greater Crested Tern & Thalasseus bergii & Piscivores & Not Dec \\
\hline & 73 & Grey Heron & Ardea cinerea & Piscivores & Dec \\
\hline & 76 & Grey-hooded Gull & Chroicocephalus cirrocephalus & Piscivores & Not Dec \\
\hline & 77 & Gull-billed Tern & Gelochelidon nilotica & Insectivores & Dec \\
\hline
\end{tabular}


Table A1. Cont.

\begin{tabular}{|c|c|c|c|c|c|}
\hline Cluster & Code & Local Name & Scientific Name & Diet Guild & Global Status \\
\hline & 78 & Hadeda Ibis & Bostrychia hagedash & Insectivores & Not Dec \\
\hline & 79 & Hamerkop & Scopus umbretta & Piscivores & Not Dec \\
\hline & 80 & Hartlaub's Gull & Chroicocephalus hartlaubii & Piscivores & Not Dec \\
\hline & 82 & Intermediate Egret & Ardea intermedia & Piscivores & Dec \\
\hline & 85 & Lesser Black-backed Gull & Larus fuscus & Piscivores & Not Dec \\
\hline & 86 & Lesser Black-winged Plover & Vanellus lugubris & Semi-omn & Not Dec \\
\hline & 87 & Lesser Crested Tern & Thalasseus bengalensis & Piscivores & Not Dec \\
\hline & 99 & Long-toed Lapwing & Vanellus crassirostris & Semi-omn & Dec \\
\hline & 101 & Madagascar Heron & Ardea humbloti & Piscivores & Dec \\
\hline & 105 & Madagascar Teal & Anas bernieri & Insectivores & Dec \\
\hline & 111 & Pied Avocet & Recurvirostra avosetta & Omnivores & Dec \\
\hline & 114 & Purple Heron & Ardea purpurea & Piscivores & Dec \\
\hline & 123 & Roseate Tern & Sterna dougallii & Piscivores & Not Dec \\
\hline & 127 & Sacred Ibis & Threskiornis aethiopicus & Insectivores & Dec \\
\hline & 129 & Sandwich Tern & Thalasseus sandvicensis & Piscivores & Not Dec \\
\hline & 132 & Southern Bald Ibis & Geronticus calvus & Insectivores & Dec \\
\hline & 133 & Southern Black-backed Gull & Larus dominicanus & Piscivores & Not Dec \\
\hline & 136 & Spotted Thickknee & Burhinus capensis & Insectivores & Not Dec \\
\hline & 145 & Three-banded Courser & Rhinoptilus cinctus & Insectivores & Not Dec \\
\hline & 147 & Eurasian Oystercatcher & Haematopus ostralegus & Insectivores & Dec \\
\hline & 148 & Water Thickknee & Burhinus vermiculatus & Omnivores & Dec \\
\hline & 153 & White-backed Night Heron & Gorsachius leuconotus & Piscivores & Not Dec \\
\hline & 154 & White-breasted Cormorant & Phalacrocorax carbo & Piscivores & Not Dec \\
\hline & 155 & White-crowned Lapwing & Vanellus albiceps & Semi-omn & Not Dec \\
\hline & 157 & White-fronted Plover & Charadrius marginatus & Insectivores & Dec \\
\hline & 163 & Yellow-billed Stork & Mycteria ibis & Piscivores & Dec \\
\hline \multirow[t]{10}{*}{3} & 22 & Black Stork & Ciconia nigra & Insectivores & Dec \\
\hline & 52 & Crowned Crane & Balearica regulorum & Semi-omn & Dec \\
\hline & 66 & Great White Pelican & Pelecanus onocrotalus & Piscivores & Dec \\
\hline & 68 & Greater Flamingo & Phoenicopterus roseus & Piscivores & Not Dec \\
\hline & 88 & Lesser Flamingo & Phoeniconaias minor & Insectivores & Dec \\
\hline & 113 & Pink-backed Pelican & Pelecanus rufescens & Piscivores & Not Dec \\
\hline & 130 & Shoebill & Balaeniceps rex & Piscivores & Dec \\
\hline & 149 & Wattled Crane & Grus carunculate & Omnivores & Dec \\
\hline & 150 & White Stork & Ciconia ciconia & Piscivores & Not Dec \\
\hline & 161 & Woolly necked Stork & Ciconia episcopus & Insectivores & Dec \\
\hline \multirow[t]{20}{*}{4} & 1 & African Black Duck & Anas sparsa & Omnivores & Dec \\
\hline & 9 & African Pygmy Goose & Nettapus auritus & Herbivores & Dec \\
\hline & 35 & Cape Shoveler & Spatula smithii & Omnivores & Not Dec \\
\hline & 36 & Cape Teal & Anas capensis & Omnivores & Not Dec \\
\hline & 50 & Corn Crake & Crex crex & Semi-omn & Not Dec \\
\hline & 57 & Egyptian Geese & Alopochen aegyptiaca & Herbivores & Dec \\
\hline & 60 & Fulvous Duck & Dendrocygna bicolor & Herbivores & Dec \\
\hline & 63 & Great Crested Grebe & Podiceps cristatus & Insectivores & Not Dec \\
\hline & 81 & Hottentot Teal & Spatula hottentota & Omnivores & Dec \\
\hline & 84 & Knob-billed Duck & Sarkidiornis melanotos & Herbivores & Dec \\
\hline & 107 & Meller's Duck & Anas melleri & Herbivores & Dec \\
\hline & 108 & Northern Mallard & Anas platyrhynchos & Omnivores & Not Dec \\
\hline & 109 & Northern Shoveler & Spatula clypeata & Insectivores & Not Dec \\
\hline & 117 & Red-billed Teal & Anas erythrorhyncha & Omnivores & Dec \\
\hline & 131 & South African Shelduck & Tadorna cana & Herbivores & Not Dec \\
\hline & 134 & Southern Pochard & Netta erythrophthalma & Herbivores & Dec \\
\hline & 137 & Spur-winged Goose & Plectropterus gambensis & Herbivores & Not Dec \\
\hline & 152 & White-backed Duck & Thalassornis leuconotus & Herbivores & Dec \\
\hline & 156 & White-faced Duck & Dendrocygna viduata & Semi-omn & Not Dec \\
\hline & 162 & Yellow-billed Duck & Anas undulata & Omnivores & Not Dec \\
\hline
\end{tabular}




\section{Appendix B}

Table A2. Results of the Akaike information criteria for the top candidate models used to model the global population trends of waterbirds in southern Africa.

\begin{tabular}{ccccc}
\hline Model & K & AICc & $\Delta$ AICc & $\mathbf{W}_{\mathbf{i}}$ \\
\hline Global trend Diet body size & 3 & 208.724 & 0 & 0.788 \\
$\begin{array}{c}\text { Global trend Waterbird cluster + diet Body size } \\
\text { Global trend Waterbird guild + number of prey }\end{array}$ & 6 & 212.534 & 3.81 & 0.117 \\
\begin{tabular}{c} 
items consumed + diet body size \\
\hline
\end{tabular} & 8 & 213.024 & 4.299 & 0.092 \\
\hline
\end{tabular}

\section{References}

1. Hockey, P.; Dean, W.; Ryan, P. Roberts Birds of Southern Africa, 7th ed.; Trustees of the John Voelcker Bird Book Fund: Cape Town, South Africa, 2005.

2. Henry, D.A.; Cumming, G.S. Can waterbirds with different movement, dietary and foraging functional traits occupy similar ecological niches? Landsc. Ecol. 2017, 32, 265-278. [CrossRef]

3. Végvári, Z.; Borza, S.; Juhász, K. The role of phylogeny and life history of migratory waterbirds in designing fishpond management plans. Ecol. Eng. 2015, 85, 288-295. [CrossRef]

4. Thackeray, S.J.; Henrys, P.A.; Hemming, D.; Bell, J.R.; Botham, M.S.; Burthe, S.; Helaouet, P.; Johns, D.G.; Jones, I.D.; Leech, D.I. Phenological sensitivity to climate across taxa and trophic levels. Nature 2016, 535, 241. [CrossRef] [PubMed]

5. Blueweiss, L.; Fox, H.; Kudzma, V.; Nakashima, D.; Peters, R.; Sams, S. Relationships between body size and some life history parameters. Oecologia 1978, 37, 257-272. [CrossRef] [PubMed]

6. Pianka, E.R. On r-and K-selection. Am. Nat. 1970, 104, 592-597. [CrossRef]

7. Sæther, B.-E.; Lande, R.; Engen, S.; Weimerskirch, H.; Lillegård, M.; Altwegg, R.; Becker, P.H.; Bregnballe, T.; Brommer, J.E.; McCleery, R.H. Generation time and temporal scaling of bird population dynamics. Nature 2005, 436, 99-102. [CrossRef] [PubMed]

8. Dingle, H. Animal migration: Is there a common migratory syndrome? J. Ornithol. 2006, 147, 212-220. [CrossRef]

9. Okes, N.C.; Hockey, P.A.R.; Cumming, G.S. Habitat use and life history as predictors of bird responses to habitat change. Conserv. Biol. 2008, 22, 151-162. [CrossRef]

10. Dodman, T.; Diagana, C.H. Conservation dilemmas for intra-African migratory waterbirds. Waterbirds World 2006, 218, 223-230.

11. Brochet, A.L.; Dessborn, L.; Legagneux, P.; Elmberg, J.; Gauthier-Clerc, M.; Fritz, H.; Guillemain, M. Is diet segregation between dabbling ducks due to food partitioning? A review of seasonal patterns in the Western Palearctic. J. Zool. 2012, 286, 171-178.

12. Julliard, R.; Clavel, J.; Devictor, V.; Jiguet, F.; Couvet, D. Spatial segregation of specialists and generalists in bird communities. Ecol. Lett. 2006, 9, 1237-1244. [CrossRef]

13. Tripet, F.; Christe, P.; Møller, A.P. The importance of host spatial distribution for parasite specialization and speciation: A comparative study of bird fleas (Siphonaptera: Ceratophyllidae). J. Anim. Ecol. 2002, 71, 735-748. [CrossRef]

14. Dall, S.R.; Cuthill, I.C. The information costs of generalism. Oikos 1997, 197-202. [CrossRef]

15. Zanchetta, C.V.; Moore, D.J.; Weseloh, D.C.; Quinn, J.S. Population trends of colonial waterbirds nesting in Hamilton Harbour in relation to changes in habitat and management. Aquat. Ecosyst. Health Manag. 2016, 19, 192-205. [CrossRef]

16. Hansen, B.D.; Menkhorst, P.; Moloney, P.; Loyn, R.H. Long-term declines in multiple waterbird species in a tidal embayment, south-east Australia. Austral Ecol. 2015, 40, 515-527. [CrossRef]

17. Cheriak, L.; Barbraud, C.; Doumandji, S.; Bouguessa, S. Diet variability in the White Stork Ciconia ciconia in eastern Algeria. Ostrich 2014, 85, 201-204. [CrossRef]

18. Tarakini, T.; Guerbois, S.; Wencelius, J.; Mundy, P.; Fritz, H. Integrating local ecological knowledge for waterbird conservation: Insights from Kavango-Zambezi transfrontier conservation area, Zimbabwe. Trop. Conserv. Sci. 2018, 11, 1-17. [CrossRef]

19. Halse, S. Diet, body condition, and gut size of Egyptian geese. J. Wildl. Manag. 1984, 48, 569-573. [CrossRef]

20. Stewart, K.; Matthiesen, D.; Leblanc, L.; West, J. Prey diversity and selectivity of the African fish eagle: Data from a roost in northern Kenya. Afr. J. Ecol. 1997, 35, 133-145. [CrossRef]

21. Arzel, C.; Elmberg, J.; Guillemain, M.; Legagneux, P.; Bosca, F.; Chambouleyron, M.; Lepley, M.; Pin, C.; Arnaud, A.; Schricke, V. Average mass of seeds encountered by foraging dabbling ducks in Western Europe. Wildl. Biol. 2007, 13, 328-336. [CrossRef]

22. Liordos, V. Foraging guilds of waterbirds wintering in a Mediterranean coastal wetland. Zool. Stud. 2010, 49, 311-323.

23. Tibshirani, R.; Walther, G.; Hastie, T. Estimating the number of clusters in a data set via the gap statistic. J. R. Stat. Soc. Ser. B Stat. Methodol. 2001, 63, 411-423. [CrossRef]

24. Charrad, M.; Ghazzali, N.; Boiteau, V.; Niknafs, A.; Charrad, M.M. Package 'NbClust'. J. Stat. Softw. 2014, 61, 1-36.

25. Mwedzi, T.; Zimunya, T.G.; Bere, T.; Tarakini, T.; Mangadze, T. Disentangling and ranking the influence of multiple stressors on macroinvertebrate communities in a tropical river system. Int. Rev. Hydrobiol. 2017, 102, 1-11. [CrossRef]

26. Burnham, K.P.; Anderson, D.R. Model Selection and Multimodel Inference; Springer: New York, NY, USA, 2002.

27. R Development Core Team. R: A Language and Environment for Statistical Computing (Internet); R Foundation for Statistical Computing: Vienna, Austria, 2018. 
28. Bere, T.; Dalu, T.; Mwedzi, T. Detecting the impact of heavy metal contaminated sediment on benthic macroinvertebrate communities in tropical streams. Sci. Total Environ. 2016, 572, 147-156. [CrossRef]

29. Guareschi, S.; Abellán, P.; Laini, A.; Green, A.; Sánchez-Zapata, J.; Velasco, J.; Millán, A. Cross-taxon congruence in wetlands: Assessing the value of waterbirds as surrogates of macroinvertebrate biodiversity in Mediterranean Ramsar sites. Ecol. Indic. 2015, 49, 204-215. [CrossRef]

30. Emmerson, M.C.; Raffaelli, D. Predator-prey body size, interaction strength and the stability of a real food web. J. Anim. Ecol. 2004, 73, 399-409. [CrossRef]

31. Austin, V.I.; Ribot, R.F.H.; Bennett, A.T.D. If waterbirds are nocturnal are we conserving the right habitats? Emu 2016, $116,423-427$. [CrossRef]

32. Griffiths, M. Identifying Gamebird Hunting 'Hotspots': Implications for Conservation. Master's Thesis, University of Cape Town, Cape Town, South Africa, 1998.

33. Ndlovu, M.; Cumming, G.S.; Hockey, P.A.; Nkosi, M.D.; Mutumi, G.L. A study of moult-site fidelity in Egyptian geese, Alopochen aegyptiaca, in South Africa. Afr. Zool. 2013, 48, 240-249. [CrossRef]

34. Ramachandran, R.; Kumar, A.; Gopi Sundar, K.S.; Bhalla, R.S. Hunting or habitat? Drivers of waterbird abundance and community structure in agricultural wetlands of southern India. Ambio 2017, 46, 613-620. [CrossRef] [PubMed]

35. Gutiérrez, R.J.; Wood, K.A.; Redpath, S.M.; Young, J.C. Conservation conflicts: Future research challenges. Curr. Trends Wildl. Res. 2016, 1, 267-282.

36. Caron, A.; Abolnik, C.; Mundava, J.; Gaidet, N.; Burger, C.E.; Mochotlhoane, B.; Bruinzeel, L.; Chiweshe, N.; Garine-Wichatitsky, M.D.; Cumming, G.S. Persistence of low pathogenic avian influenza virus in waterfowl in a Southern African ecosystem. EcoHealth 2011, 8, 109-115. [CrossRef] [PubMed]

37. Haq, R.U.; Eiam-Ampai, K.; Ngoprasert, D.; Sasaki, N.; Shrestha, R.P. Changing landscapes and declining populations of resident waterbirds: A 12-year study in Bung Boraphet wetland, Thailand. Trop. Conserv. Sci. 2018, 11, 1-17. [CrossRef]

38. Holmgaard, S.B.; Eythórsson, E.; Tombre, I.M. Hunter opinions on the management of migratory geese: A case of stakeholder involvement in adaptive harvest management. Hum. Dimens. Wildl. 2018, 23, 1-9. [CrossRef]

39. Smith, R.V.; Stafford, J.D.; Yetter, A.P.; Horath, M.M.; Hine, C.S.; Hoover, J.P. Foraging ecology of fall-migrating shorebirds in the Illinois river valley. PLoS ONE 2012, 7, e45121. [CrossRef]

40. Buelow, C.; Sheaves, M. A birds-eye view of biological connectivity in mangrove systems. Estuar. Coast. Shelf Sci. 2015, 152, 33-43. [CrossRef]

41. Boere, G.C.; Galbraith, C.A.; Stroud, D.A. Waterbirds Around the World: A Global Overview of the Conservation, Management and Research of the World's Waterbird Flyways; The Stationery Office: Edinburgh, UK, 2006; p. 960.

42. Gerwing, T.G.; Kim, J.; Hamilton, D.J.; Barbeau, M.A.; Addison, J.A. Diet reconstruction using next-generation sequencing increases the known ecosystem usage by a shorebird. Auk 2016, 133, 168-177. [CrossRef]

43. Houlahan, J.E.; Findlay, C.S.; Schmidt, B.R.; Meyer, A.H.; Kuzmin, S.L. Quantitative evidence for global amphibian population declines. Nature 2000, 404, 752-755. [CrossRef]

44. Lydeard, C.; Cowie, R.H.; Ponder, W.F.; Bogan, A.E.; Bouchet, P.; Clark, S.A.; Cummings, K.S.; Frest, T.J.; Gargominy, O.; Herbert, D.G. The global decline of nonmarine mollusks. BioScience 2004, 54, 321-330. [CrossRef]

45. Ntiamoa-Baidu, Y.A.A.; Piersma, T.; Wiersma, P.; Poot, M.; Battley, P.; Gordon, C. Water depth selection, daily feeding routines and diets of waterbirds in coastal lagoons in Ghana. Ibis 1998, 140, 89-103. [CrossRef] 